JPPKMI 1 (1) (2020)
JURNAL PENELITIAN DAN PENGEMBANGAN
KESEHATAN MASYARAKAT INDONESIA
Jttps://journal.unnes.ac.id/sju/index.php/jppkmi

\title{
Analisis Faktor Kejadian Kecelakaan Kerja pada Pekerja Industri Tahu
}

\author{
Nisatin Asilah 1, MG Catur Yuantari ${ }^{1 凶}$ \\ ${ }^{1}$ Jurusan Ilmu Kesehatan Masyarakat, Univeritas Dian Nuswantoro Semarang
}

\begin{abstract}
Info Artikel
Sejarah Artikel:

Diterima Mei 2020

Disetujui Juni 2020

Dipublikasikan Juli 2020

\section{Keywords:}

Unsafe Action, Unsafe

Condition

URL:

https://iournal.unnes.ac.i $\mathrm{d} / \mathrm{sju} /$ index.php/ippkmi /article/view/41434/173 35

Abstrak

Pendahuluan: Industri tersebar di berbagai wilayah, salah satunya pada sentra industri tahu di Kelurahan Jomblang Kecamatan Candisari Semarang. Penelitian ini bertujuan untuk mengetahui hubungan antara umur, masa kerja, lama kerja, unsafe action, unsafe condition dengan kejadian kecelakaan kerja pada pekerja industri tahu. Metode: Penelitian ini adalah penelitian kuantitatif dengan pendekatan cross sectional. Jumlah sampel dalam penelitian ini berjumlah 66 pekerja dan sampel yang digunakan adalah seluruh populasi pekerja. Instrumen penelitian menggunakan kuesioner. Uji statistik yang digunakan untuk mengetahui ada hubungan antara variabel bebas dan variabel terikat adalah uji rank spearman's. Hasil: Dari hasil penelitian menunjukkan bahwa tidak ada hubungan antara umur dengan kecelakaan kerja, tidak ada hubungan antara masa kerja dengan kecelakaan kerja, tidak ada hubungan antara lama kerja dengan kecelakaan kerja, ada hubungan antara unsafe action dengan kecelakaan kerja, dan ada hubungan antara unsafe condition dengan kecelakaan kerja pada pekerja industri tahu di kelurahan Jomblang kecamatan Candisari Semarang. Penutup: Bagi pihak industri, sebaiknya menerapkan 5R (Rapi,Ringkas, Rawat, Rajin, Resik) dan membentuk organisasi kecil terkait K3 pada industri.
\end{abstract}

\begin{abstract}
Introduction: The main reason for work accidents is unsafe action and unsafe condition. The industry is spread in various regions, one of which is in the tofu industry center in Jomblang village, Candisari subdistrict, Semarang. This study aims to determine the relationship between age, working period, length of work, unsafe action, unsafe conditions with the incidence of work accidents in tofu industry workers. Methods: This research is a quantitative research with cross sectional approach. The number of samples in this study amounted to 66 workers and the sample used was the entire working population. The research instrument used a questionnaire. The statistical test used to determine the relationship between the independent variable and the dependent variable is the Spearman's rank test. Results: The results showed that there was no relationship between age and work accident, there was no relationship between working period and work accident, there was no relationship between length of work and work accident, there was a relationship between unsafe action and work accident, and there was a relationship between unsafe conditions and work accident in tofu industry workers in Jomblang village, Candisari sub-district, Semarang. Closing: For the industry, it's better to apply $5 R$ (Neat, Concise, Caring,Diligent, Rehearsal)and form small organization related to K3 in the industry.
\end{abstract}

(C) 2020 Universitas Negeri Semarang

Alamat korespondensi:

J1. Imam Bonjol No.207, Pendrikan Kidul, Kec. Semarang

Tengah, Kota Semarang, Jawa Tengah 50131

E-mail: mgcatur.vuantari@dsn.dinus.ac.id 


\section{PENDAHULUAN}

Proses industrialisasi di Indonesia kini telah mendorong tumbuh dan berkembangnya industri di berbagai sektor dengan menerapkan teknologi dan menggunakan bermacam-macam bahan. Hal ini mempunyai dampak, khususnya terhadap pekerja yaitu berupa risiko kecelakaan kerja dan penyakit yang disebabkan akibat kerja. Salah satu upaya yang dapat dilakukan untuk menurunkan tingkat risiko atau dampak kecelakaan yaitu perlu diterapkan aturan keselamatan dan kesehatan kerja di lingkungan kerja (Budiono, 2003).

K3 (Keselamatan dan Kesehatan Kerja) telah menjadi salah satu pedoman dan ketetapan yang utama bagi ekonomi makro dan ekonomi mikro, karena keselamatan dan kesehatan kerja tidak dapat dipisahkan dari proses produksi barang hasil. Oleh karena itu, saran untuk perusahaan/industri yaitu mengurangi risiko kecelakaan dan PAK (Penyakit Akibat Kerja) karena kejadian kecelakaan dapat menimbulkan terlambatnya hasil produksi. Upaya untuk menguranginya yaitu dengan pencegahan kecelakaan yang ditujukan kepada lingkungan, mesin kerja, alat kerja, dan manusia. Setiap usaha pencegahan kecelakaan dilakukan dengan cara menghilangkan atau mengurangi penyebab kecelakaan sehingga terjadi penurunan angka kecelakaan kerja (Suma'mu, 2009).

Menurut Undang-Undang No.1 tahun 1970 mengenai keselamatan kerja, dijelaskan bahwa setiap pekerja berhak mendapatkan perlindungan dan keselamatan dalam melakukan pekerjaan di tempat kerja yang perlu terjamin keselamatannya, sehingga kewajiban dalam menerapkan K3 dalam sebuah instansi ataupun perusahaan hukumnya wajib. Dewan Keselamatan dan Kesehatan Kerja Nasional mengatakan bahwa kecelakaan kerja dapat menyebabkan terjadinya kerugian langsung dan kerugian tidak langsung. Kerugian langsung misalnya jika terjadi kecelakaan maka perusahaan akan mengalami kerugian karena harus mengeluarkan biaya pengobatan dan biaya perbaikan kerusakan sarana produksi.
Sedangkan kerugian tidak langsung misalnya yaitu kerugian hilangnya jam kerja, kerugian produksi, kerugian sosial dan menurunnya nama baik perusahaan yang dapat menimbulkan ketidakpercayaan lagi konsumen terhadap perusahaan (Septiana, 2014).

Berdasarkan data yang diperoleh dari International Labour Organization (ILO) pada tahun 2013, 1 pekerja di dunia meninggal setiap 15 detik karena kecelakaan kerja dan 160 pekerja mengalami sakit akibat kerja. Pada tahun 2012, ILO mencatat angka kematian yang disebabkan oleh kecelakaan kerja dan penyakit akibat kerja (PAK) sebanyak dua juta kasus setiap tahun (Departemen kesehatan, 2018).

Data pada Badan Pusat Statistik Kota Semarang menjelaskan bahwa jumlah pekerja di kota Semarang pada tahun 2014 yaitu sebanyak 774.140 pekerja. Sedangkan jumlah pekerja industri di kota Semarang pada tahun 2014 yaitu sebanyak 46.649 pekerja, yang terbagi menjadi 42.610 pekerja laki-laki dan 46.649 pekerja perempuan (BPS, 2017). Hal ini menunjukkan bahwa pekerja industri berjenis kelamin perempuan di kota Semarang jumlahnya lebih banyak dibandingkan jumlah pekerja industri laki-laki.

Berdasarkan penelitian Woro Riyadina yang mengatakan bahwa kejadian kecelakaan dan cedera akibat kecelakaan kerja sering terjadi maka perlu adanya peningkatan upaya untuk menurunkan angka kejadian kecelakaan kerja, yaitu dengan cara pengendalian faktor risiko melalui model intervensi yang tepat dan sesuai masing-masing jenis industri (Riyadina, 2007).

Sektor industri informal timbul karena meluapnya pekerja tetapi tidak diimbangi oleh tersedianya lapangan pekerjaan yang cukup. Salah satu industri informal yang berkembang di masyarakat adalah industri tahu. Pada umumnya, pekerja industri tahu belum mendapatkan hak pelayanan atau jaminan kesehatan dari pemilik industri terkait apabila terjadi kecelakaan kerja atau penyakit akibat kerja. Banyak industri tahu tidak tersentuh oleh peraturan pemerintah, sedangkan industri tahu di kota Semarang mempunyai prospek pasar yang menarik, yaitu dengan banyaknya restoran 
dan outlet yang menyediakan aneka makanan yang berbahan baku dari tahu, banyak juga industri tahu yang menjual tahunya dalam bentuk eceran maupun pesanan pelanggan (Fitriana, 2013).

Industri rumahan adalah industri kecil yang pada dasarnya bergerak di bidang industri informal,yang kemudian menjadi dasar salah satu industrialisasi yang ada di Indonesia. Industri sektor informal mempunyai pola kegiatan yang tidak teratur sama sekali, baik dalam hal permodalan maupun penerimaannya yang pada umunya tidak tersentuh oleh peraturan dan ketentuan yang sudah ditetapkan (Wahyuni, 2013). Industri ini tersebar di berbagai wilayah, salah satunya berada di sentra industri yang tepatnya ada di Kelurahan Jomblang Kecamatan Candisari Semarang. Beberapa industri yang ada di sentra industri tahu ini, mengolah bahan dasar pembuat tahu dengan menggunakan kedelai. Lingkungan kerja di industri ini berada pada lingkungan kerja yang panas (Ummi, 2007).

Jumlah pekerja sangat berpengaruh terhadap tumbuh dan berkembangnya usaha industri tahu (Adnaniyun dan Leady Putra, 2013). Umur pekerja mempunyai hubungan dengan kejadian kecelakaan kerja. Berdasarkan survey awal yang telah dilaksanakan dengan wawancara pada pihak industri pada bulan April 2018, terdapat 66 pekerja dari 3 industri tahu yang ada di Kelurahan Jomblang Kecamatan Candisari Kota Semarang. Untuk pekerja industri tahu yang diteliti terdiri dari pekerja perempuan dan pekerja laki-laki dengan rata-rata usia dibawah 65 tahun.

Jenis kegiatan yang dilakukan pekerja industri tahu setiap harinya yaitu melakukan kegiatan penggilingan, perebusan, percetakan. Pekerja industri tahu di Kelurahan Jomblang Kecamatan Candisari Kota Semarang sistem kerja nya yaitu pekerja bekerja selama seminggu tanpa adanya hari libur dan dengan waktu istirahat yang tidak menentu. Terdapat sistem pergantian kerja untuk pekerja yang menginginkan waktu untuk ijin istirahat atau libur. Pekerja bekerja dimulai pukul 06.00 selesai. Setiap harinya pekerja bekerja sesuai pesanan yang didapat dari tiap industri. Kegiatan setiap hari pekerja berada di lingkungan yang licin, terdapat beberapa pekerja yang tidak menggunakan alat pelindung diri (sepatu boot) dan berisiko kecelakaan kerja pada pekerja. Sedangkan alat pelindung diri mempunyai hubungan terhadap kejadian kecelakaan kerja.

Berdasarkan penelitian Muhammad Rifqialauddin dkk mengatakan bahwa terdapat potensi bahaya pada proses industri tahu serasi Bandungan Baru, antara lain seperti gerakan monoton, terjepit dan tertimpa alat press, lantai licin, terkena jamur. Terdapat juga pekerja yang terkena adonan tahu yang masih panas saat pengadonan (Rachmawati, 2016). Sedangkan dari hasil survei awal dan wawancara pada 50 pekerja di industri tahu, yang didapatkan yaitu pekerja industri tahu mengalami kejadian tersiram air panas, terjatuh, tergores, terpeleset. Maka hal tersebut merupakan beberapa kejadian kecelakaan kerja yang dialami oleh pekerja industri tahu di Kelurahan Jomblang Kecamatan Candisari Kota Semarang. Tujuan penelitian ini menganalisis faktor kejadian kecelakaan kerja pada industri tahu.

\section{METODE}

Pada penelitian ini menggunakan jenis penelitian analitik kuantitatif dengan pendekatan cross sectional. Menggunakan penelitian ini dikarenakan analisis data yang dipaparkan dalam bentuk angka-angka dan pengumpulan data dilakukan dalam waktu yang bersamaan. Variabel bebas pada penelitian ini adalah umur, lama kerja, masa kerja, unsafe action, unsafe condition serta variabel terikat dalam penelitian ini adalah kecelakaan kerja. Populasi pada penelitian ini berjumlah 66 pekerja, yang terdiri dari semua pekerja industri I sebanyak 33 pekerja, industri II sebanyak 18 pekerja, industri III sebanyak 15 pekerja. Beban kerja pada setiap industri berbeda-beda, yaitu sesuai dengan target yang dicapai pada setiap industri. Teknik pengambilan sampel pada penelitian ini, dilakukan dengan menggunakan seluruh populasi pekerja, dimana pengambilan 
sampel diambil secara keseluruhan pekerja industri tahu yang ada. Dalam penelitian ini sampel yang digunakan sebanyak 66 pekerja industri tahu.

Pengumpulan data menggunakan data primer dengan membagikan kuesioner kepada pekerja/responden, yang bertujuan untuk mengetahui data penelitian yang diperlukan terkait tentang faktor-faktor yang berhubungan dengan terjadinya kecelakaan kerja. Disamping itu juga menggunakan data sekunder yang digunakan untuk menunjang penelitian seperti untuk mengetahui jumlah data semua pekerja yang bekerja di industri tahu Kelurahan Jomblang Kecamatan Candisari Semarang. Data lainnya yaitu data yang diperoleh dari jurnal-jurnal dan buku. Metode pengumpulan data menggunakan metode wawancara dengan menggunakan pedoman wawancara serta observasi untuk mengetahui proses pengolahan tahu secara langsung. Pedoman wawancara telah dilakukan uji validitas dan reliabilitas pada pekerja Pabrik Tahu NS yang letaknya berada di Bendan Dhuwur Semarang sebanyak 30 pekerja.

Analisis yang dilakukan untuk memberikan diskripsi atau gambaran terhadap variabel yang akan menggunakan analisis univariat, serta menggunakan bivariate dengan uji statistik rank spearman's karena data yang didapat berdistribusi tidak normal.

\section{HASIL DAN PEMBAHASAN}

Proses produksi di industri tahu mempunyai risiko kecelakaan kerja, antara lain terpeleset, terjatuh, tersiram air panas, dan tergores. Setiap hari proses produksi berlangsung selama 9 sampai 10 jam/hari tanpa adanya waktu untuk istirahat (kecuali hari Jum'at disediakan waktu untuk sholat Jum'at). Minat masyarakat dalam mengkonsumsi tahu semakin hari semakin meningkat, sehingga pelaksanaan pekerjaan di industri tahu juga menjadi meningkat. Peningkatan ini dapat berisiko pekerja mengalami kecelakaan kerja. Adapun proses industry tahu hasil observasi sebagai berikut:
Proses Penggilingan

Proses pertama pembuatan tahu dimulai dari perendaman kedelai kemudian penggilingan kedelai. Tujuan perendaman kedelai yaitu agar lebih lunak untuk digiling. Hasil rendaman kemudian digiling menggunakan mesin penggiling hingga menjadi bubur kedelai. Setelah digiling, bubur kedelai kemudian diarahkan ke bagian perebusan untuk direbus menjadi bahan pembuatan tahu. Pekerja pada proses ini, setiap bekerja melakukan pekerjaan perendaman dan penggilingan kedelai yang kemudian dilanjutkan ke bagian perebusan. Faktor risiko kecelakaan kerja pada pekerja proses penggilingan yaitu terjatuh dan terpeleset. Lingkungan kerja pada proses penggilingan yang licin, terdapat genangan air dan terdapat tumpukan barang bahan dasar kedelai menyebabkan potensi kecelakaan kerja pada pekerja yaitu terjatuh dan terpeleset.

Proses Perebusan

Pada perebusan, terdapat aktifitas pekerja yaitu merebus dan menyaring sari kedelai. Hasil dari penggilingan kemudian direbus selama kurang lebih 10 sampai 15 menit. Pada saat perebusan harus beberapa kali diaduk agar tidak mengendap di dasar bak. Pengadukan dilakukan secara manual menggunakan alat pengaduk yang terbuat dari kayu. Kemudian setelah direbus, kedelai disaring dan diperas untuk mendapatkan sari kedelai. Proses perebusan dan penyaringan dilakukan secara manual oleh pekerja. Sari kedelai yang telah matang kemudian digumpalkan menggunakan air hasil fermentasi sari kedelai atau yang lebih dikenal dengan sebutan "air kecut". Setelah itu, sari kedelai yang telah menggumpal kemudian dilanjutkan pada proses pencetakan. Faktor risiko kecelakaan kerja pada pekerja proses perebusan yaitu terjatuh, terpeleset, dan tersiram air panas. Lingkungan kerja pada proses perebusan yang licin, terdapat genangan air dan terdapat tumpukan barang seperti tumpukan ampas kedelai menyebabkan potensi kecelakaan kerja pada pekerja yaitu terjatuh dan terpeleset. Sedangkan pada proses perebusan dapat berisiko terjadinya tersiram air panas pada saat 
perebusan dan penyaringan oleh pekerja industri tahu.

Proses Pencetakan

Proses pencetakan menggunakan alat cetak dari bahan dasar kayu dan alat potong menggunakan pisau dari pekerja. Proses ini digunakan untuk mencetak tahu dan mengepress gumpalan tahu agar memadat. Setelah memadat, barulah tahu dianginanginkan untuk selanjutnya dipotong berdasarkan ukuran yang diinginkan oleh industri. Faktor risiko kecelakaan kerja pada pekerja proses pencetakan yaitu terjatuh, terpeleset dan tergores Lingkungan kerja pada proses pencetakan yang licin, terdapat genangan air dan terdapat tumpukan barang hasil tahu menyebabkan potensi kecelakaan kerja pada pekerja yaitu terjatuh dan terpeleset. Sedangkan pada saat pencetakan dan pemotongan tahu pekerja berisiko terjadinya tergores alat pemotong tahu.

Karakteristik responden dapat dilihat pada tabel 1. Unsafe action yang sering dilakukan oleh pekerja industri tahu yaitu bekerja sambil mengobrol dengan rekan kerja dengan presentase $97 \%$, tidak memakai sepatu boot dengan presentase $72,7 \%$, merokok saat bekerja dengan presentase $63,6 \%$.

Berdasarkan hasil bahwa unsafe condition di industri tahu kelurahan Jomblang, pekerja merasakan bahwa terdapat genangan air di area kerja dengan presentase $100 \%$, lantai kerja yang
Tabel 1. Karakteristik Responden

\begin{tabular}{lll} 
Keterangan & Frekuensi & $\begin{array}{l}\text { Presentase } \\
(\%)\end{array}$ \\
\hline Umur & & $41 \%$ \\
$20-30$ tahun & 27 & $45 \%$ \\
$31-40$ tahun & 30 & $14 \%$ \\
$\begin{array}{l}41-50 \text { tahun } \\
\text { Masa Kerja }\end{array}$ & 9 & $56 \%$ \\
$\begin{array}{l}\text { Baru (<6 bulan } \\
-3 \text { tahun) }\end{array}$ & 37 & $44 \%$ \\
$\begin{array}{l}\text { Lama } \\
\text { tahun) }\end{array}$ & 29 & $92,4 \%$ \\
Lama Kerja & 5 & $7,6 \%$ \\
$\begin{array}{l}\text { 9 jam/hari } \\
10 \text { jam/hari }\end{array}$ & & \\
Total & 66 & $100 \%$ \\
\hline
\end{tabular}

Sumber : Data Primer (2018)

licin dengan presentase $97 \%$, area kerja sempit dengan presentase $93,3 \%$.

Presentase kecelakaan kerja di industri tahu kelurahan Jomblang kecamatan Candisari Semarang dapat dilihat pada tabel 4. Adapun hasil bivariate, yang telah dilakukan uji normalitas sebelum didapatkan data dapat dilihat pada tabel 5.Umur mempunyai pengaruh yang penting terhadap kecelakaan kerja. Golongan umur tua mempunyai kecenderungan yang lebih tinggi untuk mengalami kecelakaan akibat kerja dibandingkan dengan golongan umur muda, karena umur muda mempunyai reaksi dan kecepatan yang lebih tinggi. Namun umur muda pun sering pula mengalami kasus kecelakaan akibat kerja, hal ini mungkin karena

Tabel 2. Distribusi Frekuensi Unsafe Action

\begin{tabular}{|c|c|c|c|c|c|c|}
\hline \multirow[t]{2}{*}{ Unsafe Action } & \multicolumn{2}{|c|}{ Sering } & \multicolumn{2}{|c|}{$\begin{array}{l}\text { Kadang- } \\
\text { kadang }\end{array}$} & \multicolumn{2}{|c|}{ Tidak Pernah } \\
\hline & $\mathrm{F}$ & $\%$ & $\mathrm{~F}$ & $\%$ & $\mathrm{~F}$ & $\%$ \\
\hline Pekerja bekerja saat tubuh tidak sehat & 24 & 36,4 & 21 & 31,8 & 21 & 31,8 \\
\hline Bekerja sambil mengobrol dengan rekan kerja & 64 & 97 & 2 & 3 & 0 & 0 \\
\hline Bekerja dengan sesekali bermain $h p$ & 5 & 7,6 & 25 & 37,9 & 36 & 54,5 \\
\hline Bekerja memakai sepatu boot & 7 & 10,6 & 11 & 16,7 & 48 & 72,7 \\
\hline Merokok saat bekerja & 42 & 63,6 & 6 & 9,1 & 18 & 27,3 \\
\hline $\begin{array}{l}\text { Memeriksa terlebih dahulu kondisi peralatan } \\
\text { sebelum menggunakan }\end{array}$ & 7 & 10,6 & 45 & 68,2 & 14 & 21,2 \\
\hline Tergesa-gesa dalam bekerja & 10 & 15,2 & 39 & 59,1 & 17 & 25,8 \\
\hline Melamun saat bekerja & 2 & 3 & 11 & 16,7 & 53 & 80,3 \\
\hline $\begin{array}{l}\text { Belum mengetahui cara bekerja yang benar tetapi } \\
\text { tetap kerjakan }\end{array}$ & 0 & 0 & 6 & 9,1 & 60 & 90,9 \\
\hline Selalu membersihkan alat setelah menggunakannya & 5 & 7,6 & 38 & 57,6 & 23 & 34,8 \\
\hline
\end{tabular}

Sumber : Data Primer (2018) 
Tabel 3. Distribusi Frekuensi Unsafe Condition

\begin{tabular}{|c|c|c|c|c|c|c|}
\hline \multirow[t]{2}{*}{ Unsafe Condition } & \multicolumn{2}{|c|}{ Sering } & \multicolumn{2}{|c|}{ Kadang-kadang } & \multicolumn{2}{|c|}{ Tidak Pernah } \\
\hline & $\mathrm{F}$ & $\%$ & $\mathrm{~F}$ & $\%$ & $\mathrm{~F}$ & $\%$ \\
\hline Area kerja sempit & 62 & 93,9 & 4 & 6,1 & 0 & 0 \\
\hline Area kerja lantainya licin & 64 & 97 & 2 & 3 & 0 & 0 \\
\hline Terdapat tumpukan barang di area kerja & 42 & 63,6 & 19 & 28,8 & 5 & 7,6 \\
\hline Terdapat genangan air di area kerja & 66 & 100 & 0 & 0 & 0 & 0 \\
\hline Peralatan berserakan di area kerja & 31 & 47 & 35 & 53 & 0 & 0 \\
\hline $\begin{array}{l}\text { Terdapat barang yang mengganggu jalan di area } \\
\text { kerja }\end{array}$ & 17 & 25,8 & 45 & 68,2 & 4 & 6,1 \\
\hline $\begin{array}{l}\text { Terdapat kabel listrik yang tata letaknya tidak } \\
\text { beraturan }\end{array}$ & 30 & 45,5 & 34 & 51,5 & 2 & 3 \\
\hline Disediakan kursi untuk duduk pekerja & 64 & 97 & 2 & 3 & 0 & 0 \\
\hline Ventilasi ruang kerja baik & 59 & 89,4 & 7 & 10,6 & 0 & 0 \\
\hline Terdapat kabel yang terbuka & 0 & 0 & 7 & 10,6 & 59 & 89,4 \\
\hline
\end{tabular}

Sumber : Data Primer (2018)

kecerobohan dan sikap yang tergesagesa.(Sucipto, 2017).

Dari hasil penelitian menunjukkan bahwa nilai p-value 0,663 (p-value $>0,05$ ). Sehingga menunjukkan bahwa tidak ada hubungan antara umur dengan kejadian kecelakaan kerja pada pekerja industri tahu di kelurahan Jomblang kecamatan Candisari Semarang. Hal ini dikarenakan sebagian besar pekerja industri tahu yang ada merupakan pekerja dengan umur yang produktif yaitu kurang dari 64 tahun. Pekerja dengan umur produktif dapat mengurangi kecelakaan kerja dikarenakan pekerja dengan umur produktif lebih mempunyai kecepatan dan ketanggapan yang tinggi saat melakukan pekerjaan dibandingkan pekerja dengan umur yang tidak lagi produktif.

Menurut penelitian Sudibyo mengatakan bahwa tidak ada hubungan antara umur dengan kecelakaan kerja pada tenaga kontrak di PT. Pertamina RU VI Balongan.(Sudibyo, 2012) Hal ini dikarenakan para pekerja berumur maksimal 45 tahun, yang menunjukkan sebagian besar

Tabel 4. Distribusi Frekuensi Kecelakaan Kerja

\begin{tabular}{lllll}
\hline Kecelakaan & Ya & \multicolumn{3}{c}{ Tidak } \\
\cline { 2 - 5 } Kerja & F & $\%$ & $\mathrm{~F}$ & $\%$ \\
\hline Terjatuh & 63 & 95,5 & 3 & 4,5 \\
Terpeleset & 55 & 83,3 & 11 & 16,7 \\
$\begin{array}{l}\text { Tersiram } \\
\text { panas }\end{array}$ & 19 & 28,8 & 47 & 71,2 \\
Tergores alat & 39 & 59,1 & 27 & 40,9 \\
\hline
\end{tabular}

Sumber : Data Primer (2018) pekerja dengan umur yang produktif. Sehingga, dengan umur yang produktif dapat mengurangi kecelakaan kerja.

Umumnya fisik manusia seperti penglihatan, kecepatan reaksi akan menurun pada usia 30 tahun atau lebih.(Afni dan Prilia Nor, 2012) Sehingga untuk golongan umur 30 tahun keatas sebagian besar banyak mengalami kecelakaan kerja yang sifatnya berat.

Umur yang lebih tinggi/tua mempunyai kecenderungan lebih tinggi mengalami kecelakaan kerja dibandingkan dengan umur muda yang mempunyai kecepatan reaksi lebih tinggi.

Masa kerja merupakan faktor yang dapat mempengaruhi terjadinya kecelakaan kerja. Berdasarkan berbagai penelitian dengan meningginya pengalaman dan ketrampilan akan disertai dengan penurunan angka kecelakaan akibat kerja. Kecelakaan kerja dapat terjadi pada buruh atau pekerja yang mempunyai masa kerja dibawah 1 tahun.( Sudibyo, 2012)

Dari hasil penelitian menunjukkan bahwa nilai $p$-value 0,826 ( $p$-value $>0,05$ ). Hal ini menunjukkan bahwa tidak ada hubungan antara masa kerja dengan kecelakaan kerja. Rata-rata pekerja telah bekerja di industri tahu selama 4 tahun, dengan masa kerja paling lama yaitu 26 tahun dan masa kerja paling sedikit yaitu selama 1 tahun. Semakin lama bekerja maka tingkat kecelakaan kerja semakin sering karena masa kerja yang tinggi tidak menjamin seseorang aman dari kecelakaan kerja. 
Tabel 5. Hasil Uji Rank Spearman's

\begin{tabular}{|c|c|c|c|c|}
\hline $\begin{array}{l}\text { Variabel } \\
\text { Bebas }\end{array}$ & Variabel Terikat & $\mathrm{P}$-Value & $\begin{array}{l}\text { Koefisien } \\
\text { Korelasi }\end{array}$ & Keterangan \\
\hline Umur & Kecelakaan kerja & 0,663 & $-0,055$ & Tidak ada hubungan \\
\hline Masa Kerja & Kecelakaan kerja & 0,826 & 0,028 & Tidak ada hubungan \\
\hline Lama Kerja & Kecelakaan kerja & 0,845 & $-0,024$ & Tidak ada hubungan \\
\hline Unsafe & Kecelakaan & 0,006 & $-0,335$ & Ada hubungan, arah terbalik, \\
\hline Action & Kerja & & & kekuatan korelasi moderat \\
\hline $\begin{array}{l}\text { Unsafe } \\
\text { Condition }\end{array}$ & Kecelakaan kerja & 0,043 & $-0,250$ & $\begin{array}{l}\text { Ada hubungan, arah terbalik, } \\
\text { kekuatan korelasi rendah }\end{array}$ \\
\hline
\end{tabular}

Sumber : Data Primer (2018)

Menurut penelitian Widya Handayani mengatakan bahwa tidak ada hubungan antara masa kerja dengan kecelakaan kerja pada perajin rotan di Pitameh dan Tanah Sirah kecamatan Lubuk Begalung kota Padang.(Handayani, 2011) Hal ini dikarenakan responden bekerja di sektor informal dimana tidak terdapat ikatan kerja secara pasti sehingga kemungkinan untuk pindah kerja lebih besar.

Masa kerja berhubungan langsung dengan pengalaman kerja. Semakin lama masa kerja maka semakin tinggi pengalaman kerja pekerja tersebut, sehingga pekerja akan mampu lebih memahami tentang bagaimana bekerja dengan aman untuk menghindarkan diri mereka dari kecelakaan kerja. Tenaga kerja yang baru pada umumnya belum mengetahui secara mendalam terkait pekerjaan yang dilakukannya. Sebaliknya dengan bertambahnya masa kerja seseorang maka tambah pula pengetahuan dan ketrampilan yang dimiliki pekerja dan aspek keselamatan dari pekerja yang dilakukan. Oleh karena itu, sebaiknya pihak industri mengadakan pelatihan terkait prosedur kerja dengan meningkatkan keselamatan dan kesehatan kerja kepada pekerja yang masa kerjanya belum lama.(Suma'mur, 2009) Dilakukan pelatihan prosedur kerja dan pelatihan keselamatan dan kesehatan kerja, selain untuk meningkatkan pengetahuan pekerja, dapat juga untuk meminimalisir kecelakaan kerja dan meningkatkan produktivitas kerja.

Ketentuan atau standar waktu/lama kerja dalam satu hari yaitu 8 jam. Semakin lama seseorang bekerja maka akan timbul rasa lelah dan dapat menurunkan daya konsentrasi yang dapat berakibat terjadinya kecelakaan kerja.

Pekerja bekerja lebih dari 8 jam per harinya. Paling lama sebesar $10 \mathrm{jam} /$ hari dan paling sedikit 9 jam/hari. Pekerja dengan lama kerja 9 jam/hari dengan presentase $92,4 \%$ dan pekerja dengan lama kerja $10 \mathrm{jam} / \mathrm{hari}$ dengan presentase $7,6 \%$. Hal tersebut menunjukkan bahwa lama kerja pada pekerja industri tahu di kelurahan Jomblang Kecamatan Candisari kota Semarang belum memenuhi standar lama kerja.

Dari hasil wawancara didapatkan hasil dalam satu hari pekerja industri tahu bekerja tidak ada istirahatnya. Waktu istirahat sangat penting untuk memulihkan kondisi baik fisik maupun mental. Namun, pekerja di industri tahu kelurahan Jomblang kecamatan Candisari kota Semarang menggunakan waktu istirahat setelah selesai bekerja dan langsung kembali pulang untuk istirahat di rumah pekerja masingmasing, karena saat jam kerja tidak ada jam istirahat khusus. Hal tersebut dapat menyebabkan kelelahan yang menumpuk, sehingga risiko kecelakaan kerja lebih tinggi.

Kecelakaan kerja dapat disebabkan oleh faktor unsafe action (faktor manusia). Faktor manusia paling tinggi untuk menyebabkan kecelakaan kerja yaitu karena keteledoran manusia itu sendiri.(Anizar, 2009) Unsafe action merupakan perilaku tidak aman dan berbahaya yang dilakukan seseorang yang dapat menimbulkan kecelakaan kerja. Unsafe action terjadi disebabkan oleh beberapa faktor seperti dari karakteristik seseorang.

Unsafe action dalam penelitian ini yaitu bekerja saat tubuh tidak sehat, mengobrol saat bekerja, bermain hp saat bekerja, tidak menggunakan sepatu boot, merokok saat 
bekerja, tidak memeriksa peralatan sebelum bekerja, tergesa-gesa saat bekerja, melamun saat bekerja, belum mengetahui prosedur kerja tapi tetap mengerjakannya, tidak membersihkan alat kerja setelah selesai bekerja.

Berdasarkan hasil penelitian yang telah dilakukan terhadap 66 pekerja industri tahu dapat diketahui bahwa unsafe action tertinggi yang sering dilakukan pekerja yaitu mengobrol dan bercanda dengan rekan kerja pada saat bekerja dengan presentase $97 \%$, tidak memakai sepatu boot saat bekerja dengan presentase 72,7 $\%$, dan merokok saat bekerja dengan presentase $63,6 \%$. Sebaiknya, pekerja lebih fokus pada saat bekerja dengan tidak bercanda dengan rekan kerja pada saat bekerja, menggunakan sepatu boot saat bekerja untuk mengurangi kecelakaan kerja yang disebabkan oleh lingkungan kerja, dan juga tidak merokok saat bekerja. Namun, dari unsafe action tersebut, terdapat pekerja yang melakukan tindakan yang aman seperti mengetahui prosedur kerja seperti mengetahui alur pekerjaan setiap tahapan prosesnya dan tidak melamun saat bekerja.

Penelitian ini sejalan dengan penelitian yang dilakukan Alqia Nur Affidah mengenai pengaruh motivasi dan tindakan tidak aman terhadap kecelakaan kerja pada karyawan bagian produksi dalam masa giling shift 3 PG X kediri, bahwa terdapat hubungan antara tindakan tidak aman (berbahaya) dengan kecelakaan kerja.(Affidah, 2016) Penelitian ini juga sejalan dengan penelitian Yani Anggina yang menunjukkan bahwa ada hubungan antara unsafe action dengan kecelakaan kerja pada bengkel mobil di kecamatan Padang Utara (Yani, 2013).

Berdasarkan hasil observasi, tindakan tidak aman atau unsafe action yang sering dilakukan yaitu merokok saat bekerja, mengobrol dengan rekan kerja saat bekerja, tidak menggunakan sepatu boot. Menggunakan sepatu boot saat bekerja merupakan alat pelindung diri yang wajib digunakan pekerja, tetapi pekerja enggan menggunakan sepatu boot karena merasa sudah terbiasa dan tidak terjadi apa-apa saat bekerja. Sedangkan pada saat observasi lantai kerja terdapat genangan air dan licin, sehingga hal tersebut dapat menyebabkan kecelakaan kerja apabila pekerja tidak menggunakan alat pelindung diri seperti sepatu boot.

Dampak yang akan dirasakan pada pekerja yang tidak menggunakan alat pelindung diri yaitu menyebabkan cidera baik cidera ringan maupun cidera berat serta kecacatan pada bagian tubuh tertentu.(Anwarudin, 2016) Sebaiknya pihak industri tahu membentuk organisasi kecil seperti P2K3 yang dapat memantau dan mengawasi penerapan Keselamatan dan Kesehatan Kerja pada industri tahu agar pekerja dapat memperhatikan dan meningkatkan tindakan yang aman pada saat bekerja. Dan perlu diberikan aturan dan prosedur secara tertulis yang sesuai agar pekerja selalu memperhatikan prosedur saat bekerja dan hal tersebut jika dilakukan dengan baik maka dapat mengurangi tindakan tidak aman atau unsafe action saat bekerja dan pekerja dapat lebih waspada terhadap risiko terjadinya kecelakaan kerja.

Kecelakaan kerja dapat disebabkan oleh lingkungan yang tidak aman atau keadaan yang dapat menimbulkan kecelakaan. Sebagian besar kondisi ini disebabkan oleh rancangan ergonomi mesin, peralatan, dan lingkungan kerja yang kurang baik. Pengaturan letak yang rapi, teratur, baik dan tepat dapat memberikan kemudahan pada proses produksi.

Akses jalan di tempat kerja harus bebas dari berbagai hambatan. Kondisi lantai tidak boleh licin akibat tumpahan air maupun bahan yang digunakan saat bekerja. Terdapat akses yang memungkinkan untuk jalur evakuasi jika terjadi suatu bahaya di tempat kerja dengan dilengkapi petunjuk dan rambu-rambu yang dapat diperhatikan dengan jelas oleh pekerja (Sunardi, 2016).

Berdasarkan hasil penelitian yang telah dilakukan pada 66 pekerja industri tahu dapat diketahui bahwa unsafe condition tertinggi yaitu terdapat genangan air di area kerja dengan presentase $100 \%$, lantai kerja yang licin dengan presentase $97 \%$, dan area kerja sempit dengan presentase 93,3\%. Sebaiknya, pihak industri memperbaiki saluran air yang ada di area kerja 
agar air tidak menggenang di area kerja, kemudian rutin membersihkan lingkungan kerja untuk meminimalisir kecelakaan kerja pada pekerja industri tahu. Namun, terdapat juga tempat kerja dengan kondisi yang aman yaitu tidak terdapat kabel listrik yang terbuka.

Hasil penelitian ini sejalan dengan penelitian Vinanti Nurul Saskia yang menghasilkan bahwa faktor lingkungan mempunyai pengaruh yang besar terhadap terjadinya kecelakaan kerja.(Saskia, 2013) Menurut uraian hasil diatas, dapat menunjukkan bahwa dalam proses dan kegiatan kerja, kondisi tidak aman atau unsafe condition dapat berpengaruh terhadap terjadinya kecelakaan kerja.

Upaya untuk mencegah kondisi yang tidak aman pada area kerja industri tahu yaitu dengan cara menerapkan $5 \mathrm{R}$ di tempat kerja. 5R yaitu resik, rawat, rajin, rapi, dan ringkas. Diterapkan berguna agar ruang kerja industri tahu dapat selalu terjaga kebersihannya, peralatan kerja dapat tersusun rapi pada tempat yang sesuai dan pekerja dapat dengan mudah menjangkau serta menggunakannya. Lantai yang licin untuk rutin dibersihkan. Barangbarang yang sudah tidak digunakan agar segera dibuang agar tidak memenuhi tempat kerja. Pengecekan terhadap saluran air industri agar tidak terdapat genangan air pada area kerja. Kondisi yang aman dan nyaman dapat meningkatkan produktivitas dan kinerja para pekerja industri tahu dan dapat menurunkan angka kecelakaan kerja pada pekerja industri tahu.

\section{PENUTUP}

Kecelakaan kerja yang dialami oleh pekerja di industri tahu antara lain terjatuh $(95,5 \%)$, terpeleset $(83,3 \%)$, tersiram air panas $(28,8 \%)$, dan tergores $(59,1 \%)$. Berdasarkan hasil bivariate bahwa tidak ada hubungan antara umur, masa kerja, dan lama kerja dengan kecelakaan kerja pada pekerja industri tahu. Namun, terdapat hubungan antara unsafe action dan unsafe condition dengan kecelakaan kerja pada pekerja industri tahu.

\section{DAFTAR PUSTAKA}

Adnaniyun dan Leady Putra. 2013. Analisis Usaha Industri Tahu di Kecamatan Sragen Kabupaten Sragen. Skripsi : Fakultas Geografi Universitas Muhammadiyah Surakarta.

Affidah A Nur. 2016. Pengaruh Motivasi dan Tindakan Tidak Aman Terhadap Kecelakaan Kerja pada Karyawan Bagian Produksi Dalam Masa Giling Shift 3 PG X Kediri. Kediri : Jurnal Wiyata, 3(1).

Afni dan Prilia Nor. 2012. Faktor Penyebab Kecelakaan Kerja Di Unit Instalasi Pabrik Gula. Semarang : Unnes Journal of Public Health, 1(1)

Anizar. Teknik Keselamatan dan Kesehatan Kerja di Industri. Yogyakarta: Graha Ilmu. 2009.

Anwarudin. 2016. Faktor-Faktor Yang Berhubungan dengan Kecelakaan Kerja Pada Pekerja Bengkel Pengelasan di Kota Ungaran. Skripsi Universitas Dian Nuswantoro. Tahun 2016.

Badan Pusat Statistik Kota Semarang. 2017. Data Jumlah Pekerja Industri Kota Semarang.

Budiono, A. 2003. Bunga Rampai Hiperkes dan KK. Semarang: BP UNDIP.

Departemen Kesehatan. 2014. Angka Kematian Penyebab Kecelakaan Kerja dan Penyakit Akibat Kerja.

Fitriani, Ana Zuraida, dan Siti Erlina. 2013. Analisis Usaha Pembuatan Tahu (Studi Kasus Pada Pabrik Tahu "Berkat Sekumpul" Martapura). Ziraa'ah, 38(3).

Handayani, W. 2011. Kecelakaan Kerja Pada Perajin Rotan Di Petameh Dan Tanah Sirah Kecamatan Lubuk Begalung Kota Padang. Jurnal Kesmas, 5(2).

Rachmawati, AN. 2016. Analisis Risiko Keselamatan dan Kesehatan Kerja Pada Pekerja di Industri Tahu Desa Banyuputih Kota Salatiga. Skripsi : Fakultas Kesehatan Universitas Dian Nuswantoro.

Riyadina, W. 2017. Kecelakaan Kerja dan Cedera Yang Dialami Oleh Pekerja Industri Di Kawasan Industri Pulo Gadung. Jakarta: Makara Kesehatan, 11(1).

Saskia, VN. Implementasi Pengendalian Risiko Kecelakaan Kerja Pada Proses Grinding dan Welding. Jurnal Teknik Industri, 1(3)

Septiana, Dwi Ayu dan Mulyono. 2014. Faktor Yang Mempengaruhi Unsafe Action Pada Pekerja Di Bagian Pengantongan Urea. The Indonesian Journal of Occupational Safety and Health, 3(1).

Sucipto, CD. 2014. Keselamatan dan Kesehatan Kerja. Banten: Gosyen Publishing. 
Sudibyo,A. 2012. Analisis Deskriptif Penyebab Terjadinya Kecelakaan Kerja Pada Tenaga Kerja Kontrak Di PT. Pertamina RU VI Balongan.

Suma'mur. 2009. Higiene Perusahaan dan Kesehatan Kerja. Jakarta

Sunardi, R. 2016. Sistem Manajemen Keselamatan dan Kesehatan Kerja. Jakarta

Ummi, F.2007. Hubungan antara beban kerja dan tekanan panas dengan tingkat kelelahan pada pekerja pembuatan tahu di Kelurahan Jomblang Kecamatan Candisari Kota Semarang. Semarang
: Fakultas Kesehatan Masyarakat Universitas Muhammadiyah Semarang.

Wahyuni, T. 2013. Faktor Risiko Yang Berhubungan Dengan Kejadian Konjungtivitas Pada Pekerja Pengelasan di Kecamatan Cilacap Tengah Kabupaten Cilacap. Jurnal Kesehatan Masyarakat, 2(1).

Yani, A. 2013. Hubungan Unsafe Action dan Unsafe Condition dengan Kecelakaan Kerja pada Pekerja Bengkel Mobil di kecamatan Padang Utara. Universitas Andalas. Tahun 2013. 